\title{
KONSEP DIRI MAHASISWA PROFESI NERS DI STIKES SANTA ELISABETH MEDAN
}

\author{
Ance M. Siallagan ${ }^{*}$, Friska Ginting ${ }^{2}$, Yuni Manurung ${ }^{3}$ \\ ${ }^{1,2}$ STIKes Santa Elisabeth Medan, Indonesia \\ Email: anche.meys@gmail.com*
}

\begin{abstract}
Abstrak
Latar Belakang: Konsep diri merupakan persepsi individu terhadap dirinya sendiri supaya seseorang percaya terhadap dirinya dan menerima kondisinya. Mahasiswa perawat yang nantinya akan berhadapan dengan klien setiap harinya dalam praktik klinik maupun lapangan kerja perlu memiliki konsep diri positif, agar pelayanan keperawatan yang diberikan semakin professional. Mahasiswa program studi profesi ners yang memiliki konsep diri positif akan menunjukkan perilaku dan motivasi selama menempuh pendidikannya dan pengembangan karirnya setelah bekerja. Jika konsep diri tidak dibangun selama pendidikan maka mahasiswa profesi ners cenderung kurang percaya diri dalam pelayanan keperawatan.

Tujuan: Penelitian ini bertujuan untuk mengidentifikasi konsep diri mahasiswa yang sedang menjalani profesi ners di STIKes Santa Elisabeth Medan pada tahun 2021.

Metode: Penelitian ini menggunakan desain deskriptif eksploratif dengan pengumpulan data melalui teknik total sampling berjumlah 84 responden. Uji statistik yang digunakan adalah analisis univariat, dengan mendeskripsikan konsep diri serta komponen-komponennya secara umum.

Hasil: Hasil penelitian menunjukkan bahwa (100\%) responden memiliki konsep diri positif. Berdasarkan setiap komponen, mayoritas mahasiswa (98\%) memiliki citra tubuh yang positif, $80 \%$ memiliki ideal diri realistis, $100 \%$ memiliki performa peran memuaskan, $100 \%$ memiliki identitas personal yang jelas dan $74 \%$ memiliki harga diri yang tinggi.
\end{abstract}

Kata kunci: konsep diri; mahasiswa; profesi ners

\begin{abstract}
Background: Self-concept is an individual's perception of himself. This is very important to be studied to make sure a person believes in himself and accepts his condition. Nursing students who will be dealing with clients every day in clinical practice and in the workplace need to have a positive self-concept, so that the nursing services provided are more professional.

Objective: This study aims to describe the self-concept of students in the nursing profession program at STIKes Santa Elisabeth Medan in 2021 in general and the description of self-concept in particular based on each component of self-concept.

Methods: This study used a quantitative descriptive design with data collection through total sampling technique. The sample of this research is the nursing profession program students totaling 84 respondents.

Results: The results showed that (100\%) students of the nursing profession program had a positive self-concept. Based on each component, the majority of students (98\%) have a positive body image, $80 \%$ have a realistic self-ideal, $100 \%$ have a satisfactory role performance, $100 \%$ have a clear personal identity and $74 \%$ have high self-esteem.
\end{abstract}

Keywords: Self concept, students, nursing profession. 


\section{Pendahuluan}

Konsep diri menurut Fuhrmann (2019) merupakan konsep dasar mengenai diri sendiri, termasuk pikiran dan opini pribadi, kesadaran akan siapa dirinya, dan bagaimana perbandingan dirinya dengan orang lain, serta idealisme yang telah dikembangkannya. Konsep diri terdiri dari lima komponen yaitu citra tubuh, identitas personal, peran, ideal diri dan harga diri.Seeorang yang mampu memegang teguh komitmennya akan mempengaruhi kemampuannya dalam memecahkan masalah atau krisis identitas yang merupakan bagian dari konsep dirinya (Papalia et. al., 2017). Salah satu hal yang paling sering menjadi masalah pada masa dewasa khususnya mahasiswa adalah membuat keputusan untuk menjalani studi dalam bidang tertentu sebagai bentuk komitmen individu terhadap suatu identitas (Marcie, dalam Papalia et. al., 2017). Mahasiswa prodi ners yang menjalani pendidikan profesi perawat adalah salah satu komitmen untuk mewujudkan cita-citanya sebagai seorang perawat. Sementara itu, justru banyak terjadi remaja yang baru menyelesaikan pendidikan di perguruan tinggi mulai membangun karirnya dan bekerja di bidang yang berbeda atau tidak berkaitan dengan pendidikan yang telah dijalaninya.

Konsep diri terdiri dari dua, yakni konsep diri yang positif dan konsep diri negatif. Konsep diri positif yakni perilaku yang mengarahkan seseorang pada hal yang bernilai positif bagi dirinya seperti meningkatnya prestasi dalam dunia pendidikan baik secara akademik maupun non akademik. Mahasiswa dengan konsep diri yang positif akan memandang dirinya secara positif untuk memaksimalkan potensi diri. Konsep diri negatif merupakan tindakan yang membuat seseorang terjerumus pada hal negatif atau menjadikan individu tidak berkembang misalnya rasa malas, melawan aturan, mengancam atau mencelakai orang lain dan sebagainya (Batoran \& Wayan Sukmawati Puspitadewi, 2018).

Menurut Wijayanti dan Astiti (2017) mahasiswa keperawatan sangat penting memahami konsep diri khususnya sebelum melakukan praktik ke lahan praktik atau berkomunikasi dengan pasien dan keluarga. Kepercayaan diri penting, mengingat pelayanan keperawatan merupakan pelayanan yang profesional dimana perawat tidak hanya memberikan asuhan tetapi juga edukasi dan bimbingan. Menurut Razmus et.al (2017), sesorang yang memiliki konsep diri negatif ingin tampak berbeda lebih dari orang lain dan akan mengubah penampilannya dengan cara menggunakan barang-barang yang sedang trend dan mewah supaya dipandang baik oleh orang lain.

Mahasiswa seharusnya mampu untuk mengenali dan memahami bakat, minat dan potensi dalam dirinya. Mahasiswa yang memiliki kesadaran diri cenderung mengarahkan diri untuk berpartisipasi pada kegiatan - kegiatan yang mengembangan potensi, bakat dan minat yang dimiliki, sebaliknya jika seseorang belum memahami keadaan diri secara penuh maka ia akan bersikap malas, acuh tak acuh, bahkan tidak mengikuti kegiatan pengembangan potensi dan minatnya (Pratiwi, 2014). Pengembangan diri dapat dilakukan dengan berpartisipasi dalam organisasi baik akademik maupun nonakademik atau kegiatan kemahasiswaan yang dilaksanankan oleh kampus (Liman, 2017).

Pengenalan diri sendiri akan menjadikan seseorang mampu menerima dirinya. Individu yang mempunyai konsep diri positif pasti menerima segala bentuk informasi mengenai dirinya baik kritikan maupun saran-saran dari orang lain. Dengan kata lain, seseorang yang memiliki konsep diri positif akan memahami dan menerima berbagai fakta tentang dirinya sendiri. Kemampuan ini bukan berarti ia jarang kecewa terhadap dirinya atau bahkan gagal, melainkan individu itu tidak akan menyesali terlalu lama, justru berpikir dan bertindak untuk perbaikan diri. Selain itu mereka akan terus memperbaiki diri dengan membuat harapan serta tujuan hidup yang sesuai dan realistis. 
Artinya memiliki kemungkinan besar untuk dapat menggapai harapan tersebut. Oleh sebab itu, individu dengan konsep diri positif memiliki tempat yang luas untuk mengasimilasikan seluruh pengalamannya (Melanie, 2015).

Mahasiswa pada umumnya berada dalam rentang usia remaja akhir merupakan masa pematangan secara fisik dan psikis menuju dewasa. Mahasiswa yang menjalani program profesi ners biasanya berada pada tahap terakhir masa remaja dan di awal kedewasaan, yaitu usia 18-25 tahun. Kedewasaan individu ditunjukkan melalui konsep diri positif dan stabil. Konsep diri ini akan terbentuk saat individu telah melewati masa remaja dan memiliki pemahaman yang baik mengenai identitas dirinya. Dari kelima konsep diri, perkembangan identitas diri memiliki pengaruh yang besar dalam pembentukan konsep diri karena merupakan isu yang paling dominan pada masa remaja (Vivian, 2016). Mahasiswa yang menjalani profesi ners tahun 2021 di STIKes Santa Elisabeth Medan perlu dikaji citra tubuh, identitas personal, performa peran, ideal diri dan harga dirinya, untuk mengidentifikasi konsep dirinya masing-masing. Dengan memiliki konsep diri yang positif niscaya mahasiswa memiliki efikasi diri dan kesiapan kerja dalam memberikan pelayanan kesehatan professional. Adapun tujuan penelitian ini adalah untuk mengidentifikasi konsep diri mahasiswa profesi ners di STIKes Santa Elisabeth Medan pada tahun 2021, yang terdiri dari lima komponen yakni citra tubuh, identitas personal, performa peran, ideal diri dan harga diri.

\section{Metode Penelitian}

Metode penelitian ini adalah survey bersifat deskriptif eksploratif dengan menggunakan desain cross sectional. Variabel yang diteliti adalah konsep diri yang terbagi atas lima komponen yaitu citra tubuh, identitas personal, performa peran, ideal diri dan harga diri. Responden penelitian menggunakan teknik total sampling yaitu semua mahasiswa yang sedang menjalani program profesi ners di STIKes Santa Elisabeth Medan tahun 2021 sejumlah 84 orang. Pengumpulan data menggunakan instrument pengukuran konsep diri (Vivian, 2016) yang telah valid dan reliabel dengan nilai cronbach's alpha 0,775. Kuesioner terdiri dari 35 pernyataan yang terdiri dari 7 penyataan untuk setiap komponen konsep diri. Setelah lolos uji etik dari komite etik STIKes Santa Elisabeth Medan dengan No: 0134/KEPK-SE/PE-DT/III/2021, peneliti menjelaskan tujuan penelitian kepada responden dan memita persetujuan menjadi responden penelitian (informed consent). Kemudian responden mengisi kuesioner secara daring melalui link google form https://docs.google.com/forms/d/1F. Setelah seluruh responden mengisi link, maka peneliti melakukan download tabulasi data hasil penelitian dengan tampilan microsoft spreadsheet. Setelah ditabulasi, maka peneliti melakukan analisa univariat yang dihasilkan dalam bentuk distribusi frekuensi dan persentase..

\section{Hasil Penelitian}

Responden yang terlibat di dalam penelitian pada bulan Maret 2021 ini merupakan mahasiswa yang menjalani Program Profesi Ners pada periode tahun ajaran 2020/2021 sebanyak 84 orang.

Tabel 1. Distribusi Frekuensi Responden Menurut Umur, Jenis Kelamin, Agama dan Suku bangsa $(n=84)$

\begin{tabular}{lll}
\hline Variabel & Jumlah & Persentase \\
\hline
\end{tabular}


JINTAN : Jurnal Ilmu Keperawatan

ISSN 2774-468X (Media Online)

Vol 1, No 2, Bulan Juli 2021

Hal 119-126

\begin{tabular}{lcc}
\hline Umur & 84 & $100 \%$ \\
18-25 tahun & $\mathbf{8 4}$ & $\mathbf{1 0 0 \%}$ \\
\hline Total & 10 & $21,9 \%$ \\
\hline Jenis kelamin & 74 & $88,1 \%$ \\
Laki-laki & $\mathbf{8 4}$ & $\mathbf{1 0 0 \%}$ \\
Perempuan & & \\
\hline Total & 54 & $69,0 \%$ \\
\hline Agama & 30 & $31,0 \%$ \\
Protestan & $\mathbf{8 4}$ & $\mathbf{1 0 0 \%}$ \\
Katolik & & \\
\hline Total & 44 & $46.0 \%$ \\
\hline Suku bangsa & 24 & $32.0 \%$ \\
Batak toba & 16 & $22.0 \%$ \\
Nias & $\mathbf{8 4}$ & $\mathbf{1 0 0 \%}$ \\
\hline Karo & &
\end{tabular}

Berdasarkan umur, responden berada pada usia 18-25 tahun (100\%). Berdasarkan jenis kelamin responden mayoritas perempuan sebanyak 74 responden $(88,10 \%)$ dan laki-laki berjumlah 10 responden $(21,90 \%)$. Berdasarkan agama, responden yang beragama protestan sebanyak 54 orang $(69,0 \%)$, dan beragama Katolik berjumlah 30 responden $(31,0 \%)$. Berdasarkan suku bangsanya, responden bersuku Batak toba sejumlah 44 orang (46\%), suku Nias berjumlah 24 orang (32\%) dan suku Karo berjumlah 16 orang $(22 \%)$.

Tabel 2. Distribusi Frekuensi Responden Berdasarkan Komponen Konsep Diri ( $\mathrm{n}=84$ )

\begin{tabular}{lll}
\hline Komponen konsep diri & Jumlah & Persentase \\
\hline Citra tubuh & 83 & $98,81 \%$ \\
Positif & 1 & $1,19 \%$ \\
Negatif & $\mathbf{8 4}$ & $\mathbf{1 0 0 \%}$ \\
\hline Total & & \\
\hline Identitas personal & 84 & $100 \%$ \\
Kejelasan identitas & 0 & $0 \%$ \\
Ketidakjelasan identitas & $\mathbf{8 4}$ & $\mathbf{1 0 0 \%}$ \\
\hline Total & & \\
\hline Performa peran & 84 & $100 \%$ \\
Memuaskan & 0 & $0 \%$ \\
Tidak memuaskan & $\mathbf{8 4}$ & $\mathbf{1 0 0 \%}$ \\
\hline Total & & \\
\hline Ideal diri & 60 & $71,42 \%$ \\
Realistis & 24 & $28,58 \%$ \\
Tidak realistis & $\mathbf{8 4}$ & $\mathbf{1 0 0 \%}$ \\
\hline Total & & $53,57 \%$ \\
\hline Harga Diri & 45 & $46,43 \%$ \\
Tinggi & 39 & $\mathbf{1 0 0 \%}$ \\
\hline Tendah & $\mathbf{8 4}$ &
\end{tabular}


Sebanyak 83 responden $(98,81 \%)$ memiliki citra tubuh positif dan satu responden $(1,19 \%)$ memiliki citra tubuh negatif. Mayoritas responden menyatakan dirinya mampu menerima bentuk tubuh apa adanya, menyukai penampilan dan menganggap dirinya menarik, serta mampu menyesuaikan penampilan dengan aturan yang berlaku. Namun ada beberapa responden yang menyatakan adanya keinginan untuk mengubah beberapa bagian tubuhnya dan juga menolak menyatakan bahwa kesehatan tidak termasuk dalam prioritas pribadinya. Seluruh responden penelitian ini memiliki identitas diri yang jelas sebagai seorang mahasiswa yang sedang mengikuti program profesi ners. Seluruh responden juga mengakui performa peran yang membuat mereka puas akan dirinya yang disesuaikan dengan peran sebagai seorang calon perawat. Berdasarkan tabel 2 diperoleh data bahwa 24 responden $(28,58 \%)$ memiliki ideal diri tidak realistis, sementara 60 responden lainnya $(71,42 \%)$ memiliki ideal diri realistis. Sebanyak 45 responden $(88.2$ $\%)$ mempunyai harga diri tinggi. Sementara itu, terdapat 39 orang $(11.8 \%)$ responden dengan harga diri yang rendah.

Tabel 3. Distribusi Frekuensi Responden Berdasarkan Konsep Diri (n=84)

\begin{tabular}{lll}
\hline Konsep diri & Jumlah & Persentase \\
\hline Positif & 84 & $98,81 \%$ \\
Negatif & 0 & $1,19 \%$ \\
\hline Total & $\mathbf{8 4}$ & $\mathbf{1 0 0 \%}$ \\
\hline
\end{tabular}

Data dalam tabel di atas menunjukkan bahwa semua Mahasiswa Profesi Ners STIKes Santa Elisabeth Medan (100\%) memiliki konsep diri yang positif.

\section{Pembahasan}

Hasil penelitian menunjukkan bahwa mayoritas responden memiliki citra tubuh yang positif sebanyak $98,81 \%$ (83 orang). Sebagian besar mahasiswa profesi menyukai bentuk fisiknya dan mampu menerimanya, hanya ada 1 orang $(1,19 \%)$ yang kurang menyukai bentuk fisiknya. Hal ini membuktikan bahwa mahasiswa program profesi Ners di STIKes Santa Elisabeth Medan memiliki persepsi positif terhadap bentuk fisik dan potensi tubuhnya saat ini.

Pada masa remaja seseorang akan banyak dihadapi permasalahan, salah satunya pada aspek fisik. Keadaan fisik dapat membuat seorang remaja menjadi insecure dalam hubungan sosialnya (Darman \& Padang, 2018). Dalam penelitiannya, Darman dan Padang (2018) menyatakan bahwa citra tubuh pada mahasiswa profesi ners dipengaruhi oleh ketrampilan dalam melakukan tindakan keperawatan secara profesional. Kekurangan fisik seperti tubuh yang terlalu pendek, proporsi tubuh yang kurang sesuai akan menyebabkan kurangnya energi dan kekokohan dalam mempertahankan posisi tubuh, atau ukuran tubuh yang terlalu gemuk yang mengurangi kegesitan dalam bergerak, jantung dan sistem pernafasan yang lemah, dan kekurangan- kekurangan fisik lainnya dapat menghambat perawat memberikan tindakan keperawatan (Vivian, 2016).

Citra tubuh merupakan komponen yang memberi porsi terbesar dalam pembentukan konsep diri individu. Menurut (Hidayati \& Farid, 2016) tubuh adalah satusatunya bagian dari konsep diri yang secara kasat mata terlihat. Gambaran diri yang ideal terjadi saat individu mampu merasakan penerimaan positif terhadap dirinya sendiri. Hasil penelitian ini sejalan dengan penelitian (Saraswatia, Zulpahiyana, dan Arifah, 2015) yang menyatakan bahwa faktor fisik merupakan hal utama dalam konsep diri. Maka untuk mengembangkan konsep diri ini sebagai orangtua, guru, maupun teman tidak melakukan celaan tentang fisik seseorang yang menyebabkan seseorang menjadi tidak percaya diri atau berpandangan negatif dengan dirinya sendiri (Damarhadi et al., 2020). Menurut peneliti, responden sangat antusias dengan penampilan dirinya karena mayoritas adalah 
perempuan, tinggal di asrama yang memiliki waktu yang banyak untuk mengurus penampilan serta luasnya informasi melalui media digital yang dapat dengan mudah diakses untuk memperbaiki tampilan citra tubuh.

Hasil penelitian menunjukkan bahwa seluruh responden memiliki kejelasan identitas sebagai seorang mahasiswa yang menjalani program profesi ners. Kejelasan identitas tersebut tampak ketika responden merasa bangga menjadi mahasiswa keperawatan, tidak takut menghadapi masa depan setelah menyelesaikan perkuliahan, beranggapan karirnya akan indah dan membanggakan keluarga. Identitas personal juga terlihat dari dukungan orang tua dalam menyelesaikan profesi $(\mathrm{Mz}, 2018)$. Identitas personal merupakan kejelasan individu terhadap siapa dirinya dan mensyukuri potensi yang ada dalam dirinya (Astuti, 2007). Kejelasan identitas akan membantu seseorang menjalankan perannya dan menciptakan kepercayaan diri serta harga diri yang tinggi (Setiadi, 2018). Seluruh mahasiswa profesi Ners STIKes Santa Elisabeth Medan juga memiliki performa peran yang memuaskan, yaitu sebanyak 84 orang (100\%). Hal ini diartikan sebagai kepuasan responden terhadap perannya sebagai mahasiswa profesi Ners dimana mereka menghargai waktu praktek yang diberikan untuk mendukung perkuliahan di bidang keperawatan, bekerjasama dengan oran lain dalam menyelesaikan tugas-tugas dalam masa studi (Kamila, Karina Megasari Winahyu, 2018).

Responden dalam penelitian menunjukkan ideal diri yang realistis sebanyak 60 orang $(71,42 \%)$, dan tidak realistis sebanyak 24 orang (28,58\%). Hal ini diakibatkan oleh perasaan yang tidak menyenangkan dan selalu menyalahkan diri sendiri dalam persoalan kelompok, perasaan negatif yang muncul dari diri sendiri seperti merasa tidak di senangi oleh orang banyak. Manusia biasanya membentuk ideal diri mengacu pada faktor budaya, lingkungan kerja dan nilai- nilai pribadi yang mereka yakini (Darman \& Padang, 2018). Ideal diri tinggi atau sering disebut sifat perfeksionisme membuat seseorang menjadi ambisius akan cita-cita dan harapannya. Perfeksionisme merupakan penyebab perasaan rendah diri, karena seseorang akan merasakan lebih banyak kekecewaan ketika dirinya ternyata tidak mampu mencapai tujuan atau yang diharapkan dengan maksimal (Vivian, 2016).

Ideal diri dipengaruhi oleh faktor budaya dan keluarga (Di \& Kristen, 2017). Adanya keinginan individu untuk mengklaim dirinya sebagai sosok ideal serta keinginan untuk menghindari kegagalan mengakibatkan individu berusaha mencapai berbagai standar yang berlaku dalam lingkungan masyarakat. Realistis tidaknya ideal diri serta tinggi rendahnya harga diri seorang individu sangat mempengaruhi kesehatan jiwanya (Setiadi, 2018).

Responden penelitian memiliki harga diri tinggi sebanyak 45 orang ( $53,57 \%)$ dan 39 orang $(46,43 \%)$ mempunyai harga diri rendah. Harga diri merupakan aspek kepribadian yang pada hakikatnya dapat berkembang. Kurangnya harga diri pada mahasiswa akan dapat mengakibatkan masalah akademik dan juga dapat mengakibatkan gangguan pada proses berfikir belajar (Liman, 2017). Harga diri adalah penilaian individu tentang nilai diri sendiri. Mahasiswa keperawatan harus memiliki harga diri tinggi karena akan menentukan strategi koping terhadap stresor yang muncul selama praktik klinik dan mempengaruhi kemampuan critical thinking serta tingkat kecemasan (Kurniawati \& Harjanto, 2018). Adanya responden yang memiliki harga diri rendah diakibatkan oleh penugasan yang diberikan tidak dikerjakan tepat waktu, kurang bertanggung jawab dalam menyelesaikan tugas yang sudah diberikan oleh dosen.

Secara umum mahasiswa profesi ners di STIKes Santa Elisabeth Medan tahun 2021 memiliki konsep diri positif. Konsep diri positif yang dimiliki dengan baik oleh mahasiswa adalah tidak semata- mata didapatkan pada saat masuk ke perguruan tinggi 
melainkan bermula dari kandungan (Astuti, 2007). Kemudian setelah dewasa individu mulai memandang dirinya seperti orang-orang memandangnya dan mencoba menetapkan diri untuk pembentukan konsep diri positif. Konsep diri positif diperoleh dari proses pengalaman ketika mendapatkan masalah, memberikan respon secara emosional, dan perilaku yang ia tunjukkan secara konstan. Hal ini juga menggambarkan bahwa konsep diri positif bukanlah faktor bawaan ataupun faktor kebetulan, melainkan berkembang dari faktor pengalaman dan pendidikan (Azizi, 2015). Self-esteem atau kepercayaan bahwa dirinya berharga merupakan aspek psikologis pada diri seseorang. Berdasarkan penelitian yang dilakukan oleh Pardede (2008) menunjukkan bahwa seseorang yang memiliki harga diri yang rendah akan memandang bahwa dirinya tidak berguna dan tidak bisa diharapkan, hal tersebut menyebabkan seseorang tersebut memiliki dan mengembangkan konsep diri yang negatif. Oleh sebab itu untuk menumbuhkan konsep diri yang positif diperlukan penanaman efikasi diri yang baik (Hidayati \& Farid, 2016).

Responden penelitian berada pada rentang usia remaja akhir dan dewasa awal. Dari segi budaya mayoritas berasal dari suku batak toba, dan menganut agama protestan. Selain pendidikan yang menunjang pemahaman mahasiswa terkait koping terhadap stresor selama praktik profesi ners, budaya batak toba yang memiliki paham hamoraon, hagabeon dan hasangapon sangat mendukung konsep diri seseorang (Liman, 2017). Responden penelitian ini mayoritas berjenis kelamin perempuan $(88,1 \%)$. Menurut (Damarhadi et al., 2020) perempuan dan laki-laki pada fase remaja memiliki perbedaan konsep diri. Dari segi aspek fisiologis konsep diri perempuan lebih rendah daripada lakilaki dikarenakan seorang perempuan biasanya menemukan persoalan-persoalan pada penampilan fisiknya yang menyebabkan kurang menerima kondisi fisiknya dan merasa tidak percaya diri sehingga mereka melakukan berbagai upaya untuk memperbaiki penampilan fisiknya. Sedangkan pada laki-laki penampilan bukanlah suatu hal yang terlalu dipikirkan, sehingga pada aspek fisik laki-laki lebih memiliki konsep diri yang tinggi dibandingkan perempuan. Namun dalam penelitian ini responden perempuan dan laki-laki tidak mempunyai perbedaan signifikan dalam menilai dirinya masing-masing karena responden sudah mengenal temannya selama kuliah empat tahun, sudah mempelajari konsep diri, stres dan koping, serta kegiatan selama pendidikan profesi ners yang menyebabkan mereka mengesampingkan diri untuk perihal individual. Mahasiswa program profesi ners lebih mengutamakan kepentingan bersama selama praktik klinik profesi dibuktikan dengan jawaban item kuesioner yang menyatakan mereka sangat setuju bahwa kerjasama penting dalam mencapai tujuan dan harapan mereka selama menjadi mahasiswa.

\section{Kesimpulan}

Berdasarkan hasil penelitian dan pembahasan konsep diri mahasiswa yang menjalani program profesi ners di STIKes Santa Elisabeth Medan tahun 2021, maka dapat disimpulkan bahwa mayoritas mahasiswa program Profesi Ners STIKes Santa Elisabeth Medan memiliki konsep diri positif yaitu citra tubuh yang positif, ideal diri yang realistis dan harga diri tinggi. Seluruh mahasiswa program Profesi Ners STIKes Santa Elisabeth Medan mempunyai kejelasan identitas personal dan performa peran yang memuaskan. 


\section{Referensi}

Azizi, K. (2015). Hubungan Konsep Diri dengan Rasa Percaya Diri Mahasiswa Stain Salatiga Program Studi Pendidikan Agama Islam. 66. http://erepository.perpus.iainsalatiga.ac.id/484/1/Khoiri Azizi_11110180.pdf

Batoran, s., \& Wayan Sukmawati Puspitadewi, N. (2018). Perbedaan Konsep Diri Pada Mahasiswa Berdasarkan Status Partisipasi Dalam Unit Kegiatan Mahasiswa (Ukm) Univeristas Negeri Surabaya. Character: Jurnal Penelitian Psikologi., 5(2).

Damarhadi, S., Mujidin, M., \& Prabawanti, C. (2020). Gambaran Konsep Diri Pada Siswa SMA Ditinjau Berdasarkan Jenis Kelamin. Psikostudia: Jurnal Psikologi, 9(3), 251. https://doi.org/10.30872/psikostudia.v9i3.4392

Darman, N. A., \& Padang, U. N. (2018). Hubungan antara konsep diri dengan konformitas pada mahasiswa yang berorganisasi. 1-12.

Di, A., \& Kristen, U. (2017). Hubungan antara konsep diri dengan stres akademik pada mahasiswa papua pengguna alkohol di universitas kristen satya wacana.

Hidayati, K. B., \& Farid, M. (2016). Konsep Diri, Adversity Quotient dan Penyesuaian Diri pada Remaja Khoirul Bariyyah Hidayati. Psikologi, 5(02), 137-144.

Kamila, Karina Megasari Winahyu, W. D. (2018). Jurnal JKFT: Universitas Muhamadiyah Tangerang Hubungan antara Konsep Diri dan Motivasi Belajar Mahasiswa Keperawatan Tingkat I \& II di Universitas Muhammadiyah Tangerang Oleh Fakultas Ilmu Kesehatan Universitas Muhammadiyah Tangerang Kamila Jurnal JKFT. Jurnal JKFT: Universitas Muhamadiyah Tangerang, 2, 1-6. file:///C:/Users/User/AppData/Local/Packages/Microsoft.MicrosoftEdge_8wekyb3d 8bbwe/TempState/Downloads/1986-4584-1-SM (3).pdf

Kurniawati, K. E., \& Harjanto, T. (2018). Hubungan Harga Diri dan Komunikasi Terapeutik Mahasiswa Profesi Keperawatan. Jurnal Persatuan Perawat Nasional Indonesia (JPPNI), 2(3), 144. https://doi.org/10.32419/jppni.v2i3.91

Liman, A. P. K. (2017). KONSEP DIRI MAHASISWA PAPUA DI YOGYAKARTA (Studi Deskriptif pada Mahasiswa Papua yang Tinggal di Asrama Marauke Yogyakarta Tahun Kuliah 2016/2017 dan Implikasinya Terhadap Usulan Topik-topik Bimbingan Pribadi-Sosial). https://repository.usd.ac.id/12091/

Mz, I. (2018). Peran Konsep Diri Terhadap Kedisiplinan Siswa. NALAR: Jurnal Peradaban Dan Pemikiran Islam, 2(1), 1. https://doi.org/10.23971/njppi.v2i1.915

Pratiwi, Y. (2014). Gambaran konsep diri pada klien dewasa muda dengan kolostomi permanen di yayasan kanker indonesia jakarta pusat. 1, 1-134.

Setiadi, Y. (2018). Hubungan Konsep Diri, Kecerdasan Emosional, dan Kecemasan Belajar dengan Prestasi Belajar Mahasiswa. JNPM (Jurnal Nasional Pendidikan Matematika), 2(1), 119. https://doi.org/10.33603/jnpm.v2i1.1066

Vivian, D. (2016). Konsep Diri Mahasiswa Program Profesi Ners di Fakultas Keperawatan Universitas Sumatera Utara. 